\title{
Plasmid Profile of Bacteria
}

\author{
O.V. Olagoke ${ }^{1,2^{*}}$, O.O. Oyewale ${ }^{3}$, M.O. Olufehinti ${ }^{3}$ and B.S. Adesina ${ }^{3}$ \\ ${ }^{1}$ Department of Microbiology, Obafemi Awolowo University, Ile-Ife \\ ${ }^{2}$ Department of Agricultural Development Management (ADEM), ${ }^{3}$ Department of Rural \\ Development and Gender Issue (RUDEG), Agricultural and Rural \\ Management Training Institute (ARMTI) Ilorin \\ *Corresponding author
}

\section{A B S T R A C T}

\begin{tabular}{|c|c|}
\hline & \multirow{4}{*}{$\begin{array}{l}\text { Plasmid induces the production of extra-cellular enzymes called } \beta \text {-lactamases, and also, } \\
\text { encoded resistance genes which are often located within genetic elements. This study } \\
\text { evaluated the plasmid profile of bacterial isolates cultured from urine samples of HIV } \\
\text { seropositive pregnant women that attended antenatal clinic of the Ondo State Specialist } \\
\text { hospital, Akure. Plasmid analysis of bacterial isolates was also done by alkaline method. } \\
\text { The resistance gene (plasmid) was detected in E. coli and Pseudomonas aeruginosa } \\
\text { isolates used. The study concluded that appearance of the resistance genes in some of these } \\
\text { bacterial isolates could help the isolates to be multidrug resistant which may lead to a } \\
\text { serious public health challenges. }\end{array}$} \\
\hline & \\
\hline Article Info & \\
\hline & \\
\hline
\end{tabular}

\section{Introduction}

Healthcare associated infections are a problem globally (Mbim et al., 2016). The widespread use of antibiotics continues to influence this menace giving rise to antibiotic-resistant bacteria in the hospital setting and among immunocompromised patients (Bereket et al., 2012).

Also, Studies done by Olagoke et al., (2017) clarified that most of the bacterial isolates cultured from urine samples of HIV seropositive pregnant women were multiresistant to different antibiotics tested in vitro but some of the isolates were sensitive to ciprofloxacin. The environment of the hospital is an obvious important focus for the selection and spread of multi-resistant bacteria and a possible direct source of nosocomial infections (Russotto et al., 2015; Betteridge et al., 2013). The development of resistance by bacteria species against these agents through various mechanisms including the acquisition of extra- chromosomal elements called plasmids which induces the production of extra-cellular enzymes called $\beta$-lactamases (Elizabeth et al., 2016). Most of integrons are located within transposons that contribute to the vertical transmission, favouring their mobilization between plasmids and the bacterial chromosome by transposition events (Carattoli et al., 2001). Resistant genes are also known to be located on extra- 
chromosomal genetic elements or in segments inserted within the chromosome that originate from other genome. However, resistance genes encoded in plasmids are often located within genetic elements (Carattoli, 2003). There are speculations that resistance to $\beta$ lactam agents has influenced resistance of bacteria to other classes of antibiotics such as the quinolones and aminoglycosides with its attendant effect more devastating most especially on immune compromised patients (Amaya et al., 2012). Therefore, this study is aimed at determining the plasmid profile of selected multidrug resistant bacteria isolates recovered from Urine Sample of HIV Seropositive Pregnant Women.

\section{Materials and Methods}

\section{Sample collection}

Bacterial isolates (Escherichia coli and Pseudomonas spp) cultured from the urine samples of HIV seropositive pregnant women attending antennal clinic at the Ondo State Specialist Hospital, Akure, South western, Nigeria were used for the study. Each bacterial isolate was verified using cultural morphology, Gram's staining, selective media and differential media as well as biochemical tests to authenticate each isolate's identity.

\section{Plasmid analysis}

Plasmid analysis of selected bacterial isolates was done by method of Kado and Liu, 1981. $600 \mu 1$ of nucleic lysis solution was used to suspended the bacterial and Centrifuged for 5 min. Thereafter, protein extraction was done by added $200 \mu \mathrm{l}$ of phenol/chloroform $(1: 1)$ together with $3 \mu \mathrm{l}$ of $5 \mathrm{M}$ sodium chloride to the lysate for precipitation of chromosomal DNA and incubated on ice for $4 \mathrm{~h}$. The mixture was centrifuged for $10 \mathrm{~min}$. Thereafter, $150 \mu \mathrm{l}$ of supernatant was transferred into new tube and added with 300 $\mu \mathrm{l}$ of cold $80 \%$ ethanol and spun $20 \mathrm{~min}$ at
13, $000 \mathrm{rpm}$. The desired lysate (supernatant) was removed and washed the pellet with 100 $\mu 1$ of cold $80 \%$ ethanol and then left to air-dry before suspended in TAE with RNase (1:100) dilution. All preparations were visualized by combing $2 \mu \mathrm{l}$ of loading dye with $8 \mu \mathrm{l}$ of plasmid preparations and electrophoresed on a $0.8 \%$ agarose gel for $1 \mathrm{~min}$ at $200 \mathrm{v}$ before bringing the voltage down to $100 \mathrm{v}$ for the next $59 \mathrm{~min}$. The gels were seeded with ethidium bromide solution for $30 \mathrm{~min}$ and distained for about $1 \mathrm{~h}$ with distilled water. Thereafter, the bands were visualized and photographed under Ultra-violent illumination.

\section{Results and Discussion}

Antimicrobial drug resistance can occur by point mutations in the bacterial genome or through horizontal transfer of genetic elements carrying resistance genes. Resistance may be disseminated through clonal expansion of drug-resistant strains or through horizontal transfer of genetic elements coding for resistance determinants.

Plasmid is an important feature contributing to the dissemination of antibiotic resistance among bacteria most especially Gram negative bacteria. In this study, ten (10) E. coli isolates were used for plasmid analysis, nine were found to have plasmid; two of the twenty (20) Pseudomonas spp (Pseudomonas aeruginosa13and Pseudomonas fluorescens-7) isolates tested also produced plasmid while $S$. aureus isolates screened for plasmid was found to be plasmidless. The reason for this may be that resistance in $S$. aureus used may be chromosomal borne. Studies have shown that S. aureus acquire resistance through horizontal gene transfer and this acquisition especially the MecA genes which are on mobile genetic elements called Staphylococcal cassette chromosome which code for penicillin binding proteins (PBPs) (Giguere, 2006) (Fig. 1 and 2). 
Fig.1 Gel for E. coli plasmid DNA band

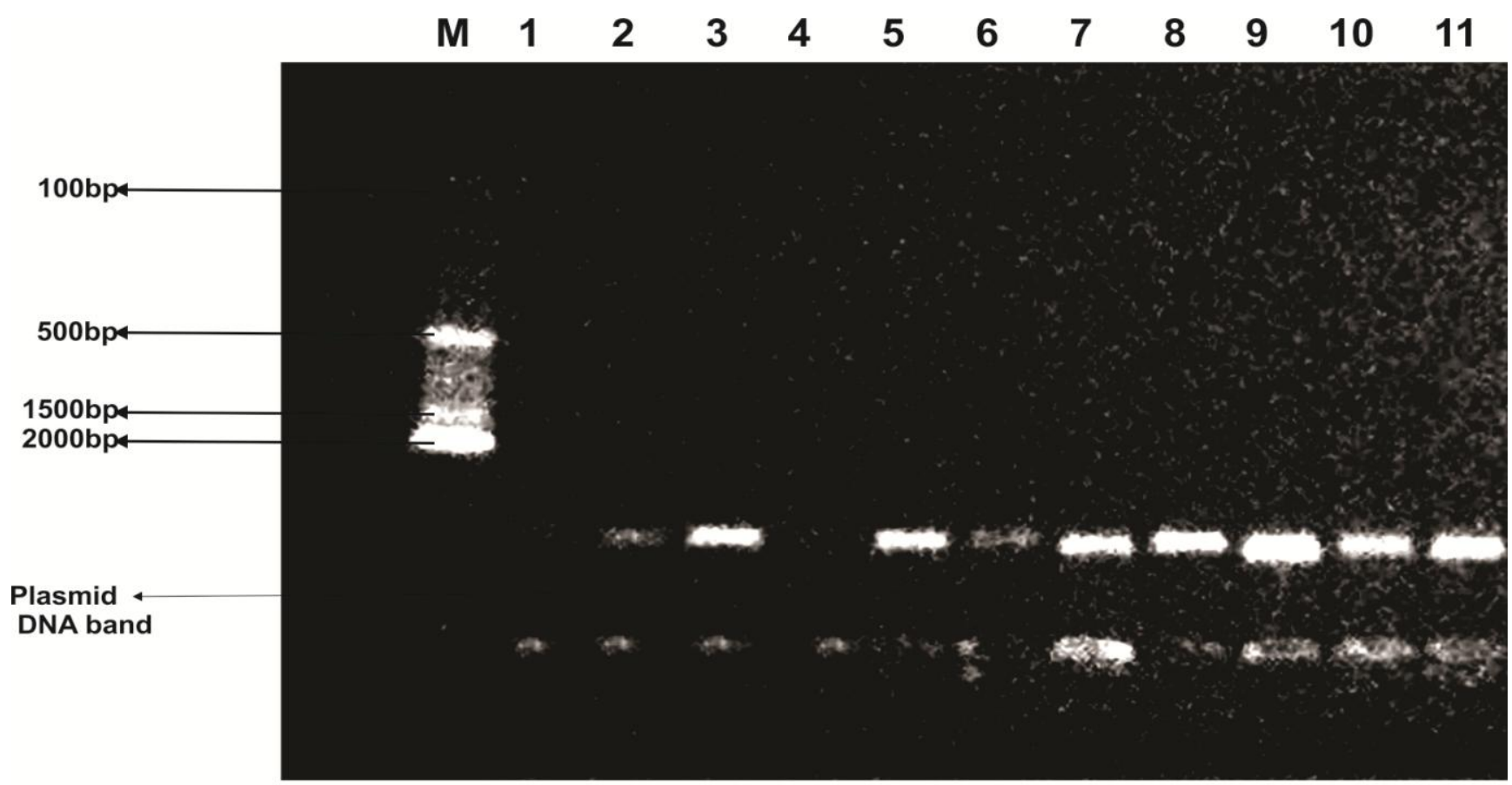

Plasmid analysis profile. Lane M: 1kb DNA Ladder; Lane 1: E.Coli Control (NCIB 86); Lane 2 to 11: E.Coli samples recovered from urine culture of HIV seropositive pregnant women

Fig.2 Gel for Pseudomonas aeruginosa and Pseudomonas fluorescens plasmid DNA band

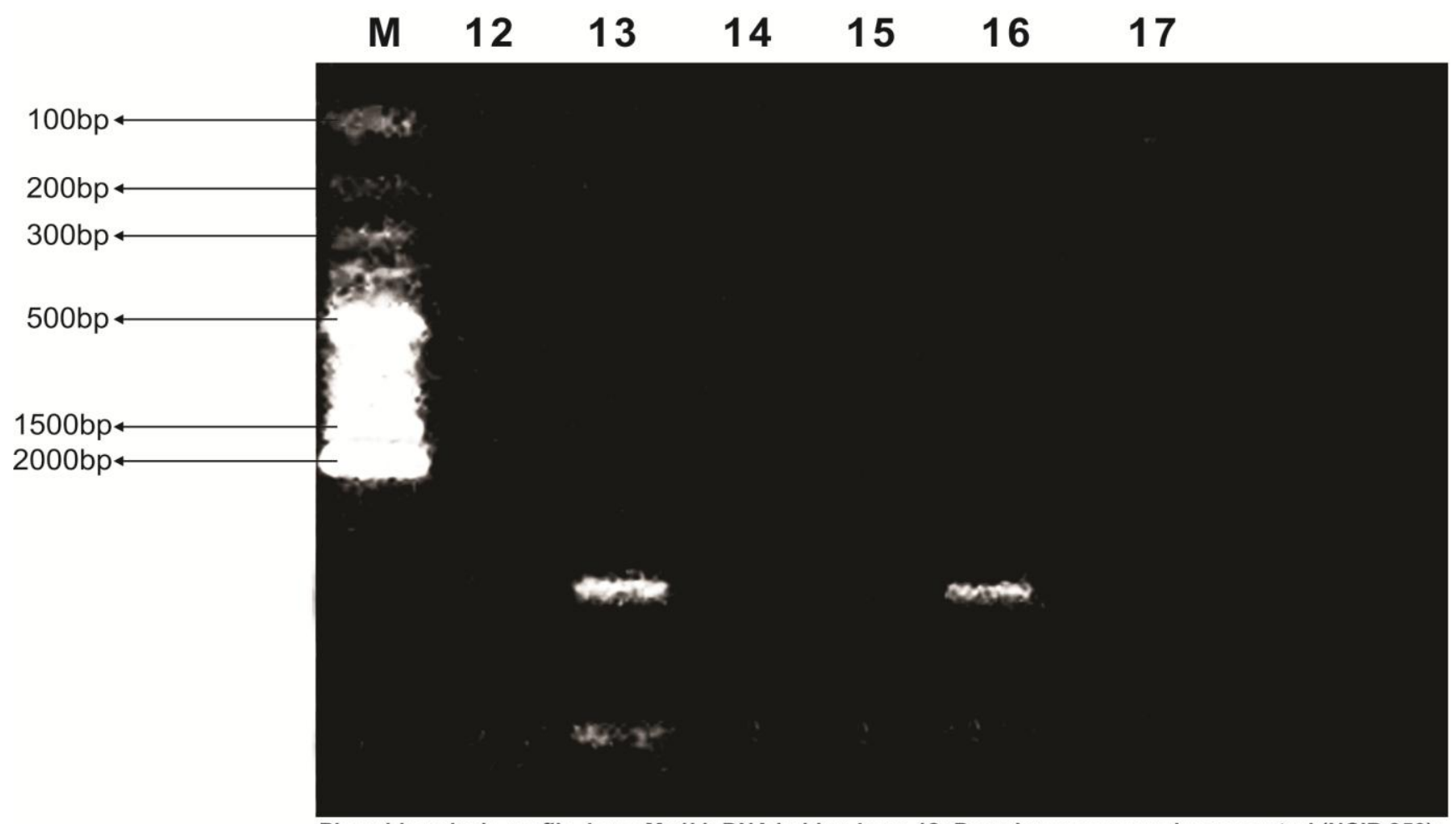

Plasmid analysis profile. Lane M: 1kb DNA ladder; Lane 12: Pseudomonas aeruginosa control (NCIB 950); Lane 13 to 17 : Pseudomonas sp samples recovered from urine culture of HIV seropositive pregnant 
Table.1 Profile of plasmid DNA recovered from bacterial isolates

\begin{tabular}{|l|l|l|l|l|}
\hline S/N & Code & Organisms & Plasmid Size (bp) \\
\hline $\mathbf{1}$ & NCIB 86 & Escherichia coli (control) & ND \\
\hline $\mathbf{2}$ & A39b+ & Escherichia coli & 6595 \\
\hline $\mathbf{3}$ & A43a+ & Escherichia coli & 6595 \\
\hline $\mathbf{4}$ & A34a+ca & Escherichia coli & ND \\
\hline $\mathbf{5}$ & A34a+ & Escherichia coli & 7129 \\
\hline $\mathbf{6}$ & A5b+ & Escherichia coli & 6595 \\
\hline $\mathbf{7}$ & A33a+ & Escherichia coli & 9004 \\
\hline $\mathbf{8}$ & A20a+mac & Escherichia coli & 7706 \\
\hline $\mathbf{9}$ & A31c+ & Escherichia coli & 7706 \\
\hline $\mathbf{1 0}$ & A40a+ & Escherichia coli & 9004 \\
\hline $\mathbf{1 1}$ & A2a+ & Escherichia coli & 7706 \\
\hline $\mathbf{1 2}$ & NCIB 950 & Pseudomonas aeruginosa (control) & ND \\
\hline $\mathbf{1 3}$ & B4c+ & Pseudomonas aeruginosa & 9004 \\
\hline $\mathbf{1 4}$ & A38b+mac & Pseudomonas fluorescens & ND \\
\hline $\mathbf{1 5}$ & A37a+ & Pseudomonas aeruginosa & ND \\
\hline $\mathbf{1 6}$ & B17b+ & Pseudomonas aeruginosa & 9004 \\
\hline $\mathbf{1 7}$ & A16a+ca & Pseudomonas fluorescens & ND \\
\hline
\end{tabular}

The studies done by Stuart (2002) shown that the appearance of the resistance genes in a clinical isolate and in a clinical setting is a serious warning to clinicians to control use of the new drug. The presence of this plasmid profile confirmed the amplification of these isolates pathogenicity factor gene and Salmonella invasive factor gene. The study concluded that appearance of the resistance genes in some of these bacterial isolates could help the isolates to be multidrug resistant which may lead to a serious public health challenges (Table 1).

This work was carried out in collaboration among all authors. Authors OVO, OOO, MOO and SBA designed the study; authors OVO wrote the protocol and interpreted the data, anchored the field study, gathered the initial data and performed preliminary data analysis. While authors $\mathrm{OVO}$ and $\mathrm{OOO}$ managed the literature searches and produced the initial draft. All authors read and approved the final manuscript.

\section{References}

Amaya, E., Reyes, D., Paniagua, M., Calderon, S., Rashid, M.U., Colque, P., Kuhn, I., Mollby, R., Weintraub, A., Nord, C.E. (2012). Antibiotic resistance patterns of Escherichia coli isolates from different aquatic environment sources in leon, Nicaragua. Clinical Microbiological Infections. 18:347-54.

Bereket, W., Hemalatha, K., Getenet, B., Wondwossen, T., Solomon, A., Zeynudin, S., Kannan, S. (2012). Update on bacterial nosocomial infections. European Review for Medical and Pharmacological Science. 16: 1039-1044

Betteridge, T., Merlino, J., Natoli, J., Cheong, E.Y., Gottlieb, T., Stokes, H.W. (2013). Plasmid and bacterial strains mediating multidrug- resistant hospital-acquired infections are co-residents of the hospital environment. Microbial Drug Resistance. 19: 104-9. 
Caratoli A, Villa L, Pezzella C, Bordi E, Visca P (2001). Expanding Drug Resistance through integron acquisition by IncFI plasmids of Salmonella enterica Typhimurium. Emerg Infect Dis., 7; 444-447.

Carattoli, A. (2003). Plasmid-mediated antimicrobial resistance in Salmonella enterica. Curr. Mol. Biol., 5 (4): 113122.

Elizabeth, N.M., Clement, I.M., Uwem, O.E. (2016). Plasmid Profile Analysis and Curing of Multidrug Resistant Bacteria Isolated from Two Hospital Environments in Calabar Metropolis, Nigeria. Asian Journal of Medicine and Health. 1 (1): $1-11$.

Giguère, S. (2006). Antimicrobial Drug Action and Interaction: An Introduction. Antimicrobial therapy in Veterinary Medicine 4th edition

Kado, C.I., Liu, S.T. (1981). Rapid Procedure for detection and Isolation of Large and Small Plasmid. Journal of Bacteriology. 145 (3): 1365-73
Mbim, E.N., Mboto, C.I., Agborn, B.E. (2016). A review of nosocomial infections in Sub-Saharan Africa. British Microbiology Research Journal. 15: 1-11.

Olagoke, O.V., Aborisade, A.B., Olasupo, A.D. (2017). Antibiotic Resistance Profile of Bacterial Isolates Cultured from Urine Samples of HIV Seropositive Pregnant Women. Microbiology Research Journal International. 21(4): 1-10; ISSN: 24567043

Russotto, V., Cortegiani, A., Raineri, S.M., Giarratano (2015). Bacterial contamination of inanimate surfaces and equipment in the intensive care unit. American Journal of Intensive Care. 10 (3): 54

Stuart, B.L. (2002). Factor impacting on the problem of antibiotic resistance. Center for adaptation Genetic and Drug Resistance, Tufts University school of Medicine, Boston. MA02111, USA. Journal of Antimicrobial Chemotherapy. 49, 25-30

\section{How to cite this article:}

Olagoke, O.V., O.O. Oyewale, M.O. Olufehinti and Adesina, B.S. 2018. Plasmid Profile of Bacteria. Int.J.Curr.Microbiol.App.Sci. 7(06): 172-176.

doi: https://doi.org/10.20546/ijcmas.2018.706.021 